\title{
PENERAPAN LEARNING MANAGEMENT SYSTEM DAN BLENDED LEARNING SEBAGAI ALTERNATIF MODEL MERDEKA BELAJAR DI MASA ADAPTASI KEBIASAAN BARU PEMBELAJARAN AGAMA KRISTEN
}

\author{
Herlina Verawati \\ (herlina1980yes@gmail.com)
}

\begin{abstract}
This paper describes the application of the Learning Management System and Blended Learning in the learning process of Christianity. The application of this learning system as an alternative to the Free Learning model during the adaptation period for New Normal in grade 4 Semester 1 students of SDN 8 Selat Hilir for the 2020/2021 academic year. The method used in this research is Classroom Action Research. The results showed that the application of the learning system used by Christian Religious Education teachers proved successful in improving student learning outcomes. This can be explained that in the pre-cycle the average score of student learning scores was 56.25 with 1 in 4 students completing. Furthermore, it increased in the first cycle, namely 68.75 with 2 students completing. Then in cycle II it increased again, namely 85.94 with 3 students who completed out of 4 students in class 4 Semester 1 in the 2020/2021 academic year at SDN 8 Selat Hilir.

Likewise, the percentage of completeness increased from Pre-cycle $25 \%$, increased in cycle I by 50\%, and increased again to $70 \%$ in cycle II.
\end{abstract}

Keywords: learning management system, blended learning, new normal

\section{A. PENDAhUluan}

Tulisan ini bertujuan untuk menganalisis penerapan Learning Management System dan Blended Learning sebagai alternatif model Merdeka Belajar Di Masa Adaptasi Kebiasaan Baru Pembelajaran Agama Kristen di Kelas IV Semester 1 Tahun Pelajaran 2020/2021 di SDN 8 Selat Hilir. Tidak bisa dipungkiri bahwa pandemi Corona Virus 19 (covid-19) telah mengubah proses pembelajaran dan model belajar di sekolah. Berkaitan dengan kondisi pandemi ini, perlu alternatif pembelajaran untuk menunjang kualitas pembelajaran yang baik. Penerapan Learning Management System (LMS) dan Blended Learning sebagai alternatif model Merdeka Belajar di masa adaptasi kebiasaan baru (New Normal), perlu untuk diujicobakan dalam proses pembelajaran agama Kristen di kelas.

Uji coba sistem pembelajaran ini penting dalam kaitannya dengan kualitas dan pencapaian tujuan pembelajaran agama Kristen itu sendiri. Terlebih dalam peran guru agama Kristen dalam mendampingi peserta didik dalam menyikapi persoalan pandemi covid-19. Desti Samarenna menjelaskan, informasi yang diberitakan setiap hari oleh media mengenai COVID-19 justru mengikis kepercayaan kepada Tuhan. Orang percaya mulai terintimidasi dengan dunia dan lebih percaya pendapat dunia dari pada jaminan dalam firman-Nya. ${ }^{1}$ Untuk itu, peran guru Pendidikan Agama

\footnotetext{
${ }^{1}$ Desti Samarenna, "WABAH COVID-19 DAN JAMINAN PERLINDUNGAN ALLAH DALAM MAZMUR 23," SHIFTKEY (JURNAL TEOLOGI DAN PENGEMBANGAN PELAYANAN) 10, no. 1 (2020).
} 
Kristen (PAK) sangat penting dalam mengatasi persoalan ini. Kualitas pembelajaran yang baik sangat menentukan kualitas lulusan yang baik dan menjawab kebutuhan pengguna jasa pendidikan. ${ }^{2}$

LMS merupakan sistem pembelajaran dengan menggunakan aplikasi perangkat lunak untuk kegiatan pembelajaran daring atau online. Pembelajaran elektronik (e-learning program) dan Blended Learning adalah metode pembelajaran yang memadukan pertemuan tatap muka dengan materi online secara harmonis. Perpaduan antara pembelajaran konvensional dimana pendidik dan peserta didik bertemu langsung dengan pembelajaran secara online yang dapat diakses kapan saja dan dimana saja. Berkaitan dengan sistem pembelajaran ini, penulis menemukan persoalan di lokasi penelitian yang sekaligus menjadi pokok pembahasan dalam penelitian ini. Pada observasi awal sebelum penerapan LMS dan Blended Learning, hasil belajar peserta didik masih rendah pada mata pelajaran PAK. Hasil belajar ini berkaitan dengan materi "Memahami Kehadiran Allah Dalam Berbagai Peristiwa Kehidupan.” Hasil belajar peserta didik terhadap materi ini rata-rata kelas adalah 56,25 dengan 1 peserta didik tuntas atau 25\% dari seluruh peserta didik di kelas 4 Semester 1 Tahun Pelajaran 2020/2021 Di SDN 8 Selat.

Hasil observasi aktivitas peserta didik berikutnya yang dilakukan di kelas kelas 4 Semester 1 Tahun Pelajaran 2020/2021 Di SDN 8 Selat Hilir, yaitu pada saat pembelajaran berlangsung, peserta didik kurang berperan aktif. Pembelajaran didominasi oleh guru PAK. Sebagian besar peserta didik hanya mendengarkan dan mencatat penjelasan dari guru. Kondisi ini membuat proses pembelajaran kurang menyenangkan. Selain itu juga mempengaruhi hasil belajar peserta didik. Berkaitan dengan permasalahan hasil belajar peserta didik di atas, perlu inovasi dan kreativitas pembelajaran yang dilakukan oleh guru PAK. Rinto Hasiholan Hutapea menegaskan bahwa guru PAK yang kreatif akan dapat meningkatkan hasil belajar peserta didik. Peran guru PAK yang keratif ini mengacu pada kreativitas guru PAK dalam menggunakan berbagai motode atau model pembelajaran. ${ }^{3}$ Selain itu, pemanfaatan media pembelajaran di era New Normal saat ini juga penting sebagai bagian dari kreativitas guru. Tantri Yulia menegaskan bahwa Peserta didik belajar melalui panca indera, baik indera penglihatan, pendengaran, perabaan, penciuman, dan merasakan. Namun, indera yang dominan digunakan dalam belajar yaitu melihat (visual), mendengar (auditori) dan merasakan (touch). ${ }^{4}$ Pendidik yang pemaham gaya belajar peserta didik akan dapat membantu peserta didik belajar secara maksimal, terutama penyesuaian belajar di masa New Normal. Melalui gagasan ini, diharapkan guru PAK dapat meningatkan kualitas pembelajaran peserta didik, khususnya pada masa adaptasi kebiasaan

${ }^{2}$ Gidion, Gidion. "Kecakapan Lulusan Pendidikan Tinggi Teologi Menghadapi Kebutuhan Pelayanan Gereja dan Dunia Pendidikan Kristen." KURIOS (Jurnal Teologi dan Pendidikan Agama Kristen) 6.1 (2020): 73-86.

${ }^{3}$ Rinto Hasiholan Hutapea, "Model Pembelajaran Kooperatif Tipe Make a Match Dalam Pendidikan Agama Kristen," SOTIRIA: Jurnal Teologi dan Pelayanan Kristiani 3, no. 1 (2020): 1-10.

${ }^{4}$ Tantri Yulia, "PENGGUNAAN MEDIA PEMBELAJARAN OLEH PENDIDIK PAK SEMESTER GENAP TA 2016-2017 DI STT KRISTUS ALFA OMEGA SEMARANG," SHIFTKEY (JURNAL TEOLOGI DAN PENGEMBANGAN PELAYANAN) 7, no. 2 (2017). 
baru (New Normal) di kelas 4 Semester 1 Tahun Pelajaran 2020/2021 SDN 8 Selat Hilir Kecamatan Selat, Kabupaten Kapuas, Kalimantan Tengah.

Berdasarkan pembahasan di atas, rumusan masalah dalam penelitian ini adalah bagaimana penerapan Learning Management System dan Blended Learning sebagai alternatif model merdeka belajar di masa adaptasi Kebiasaan Baru (New Normal)? Serta bagaimana implementasi sistem pembelajaran tersebut dalam meningkatkan kualitas pembelajaran agama Kristen di kelas 4 Semester 1 Tahun Pelajaran 2020/2021 Di SDN 8 Selat Hilir? Adapun tujuan penelitian ini adalah untuk mengetahui implementasi dari penerapan Learning Management System dan Blended Learning sebagai alternatif model merdeka belajar di masa adaptasi Kebiasaan Baru (New Normal di kelas 4 Semester 1 Tahun Pelajaran 2020/2021 Di SDN 8 Selat Hilir. Untuk mencapai tujuan penelitian ini, penulis menggunakan pendekatan atau metode Penelitian Tindakan Kelas (PTK).

\section{Learning Management System}

Learning Management System (LMS) adalah aplikasi perangkat lunak untuk kegiatan online, program pembelajaran elektronik (e-learning program), dan isi pelatihan. ${ }^{5}$ Sebuah LMS yang kuat harus bisa melakukan hal berikut: pertama, menggunakan layanan "self-service" dan "self-guided." Kedua, mengumpulkan dan menyampaikan konten pembelajaran dengan cepat. Ketiga, mengkonsolidasikan inisiatif pelatihan pada platform berbasis "web scalable." Keempat, mendukung portabilitas dan standar. Kelima, personalisasi isi dan memungkinkan penggunaan kembali pengetahuan.

LMS sebagian besar berbasis web. Dibangun dengan menggunakan berbagai platform pengembangan, seperti Java/J2EE, Microsoft.NET atau PHP. Platform ini biasanya menggunakan database seperti MySQL, Microsoft SQL Server atau Oracle sebagai back-end. Meskipun sebagian besar sistem secara komersial dikembangkan dan memiliki lisensi perangkat lunak komersial ada beberapa sistem yang memiliki lisensi open source. Misalnya, MOODLE (Modular Object-Oriented Dynamic Learning Environment) adalah paket perangkat lunak yang diproduksi untuk kegiatan belajar berbasis internet dan situs web yang menggunakan prinsip social constructionist pedagogy. ${ }^{6}$ MOODLE merupakan salah satu aplikasi dari konsep dan mekanisme belajar mengajar yang memanfaatkan teknologi informasi, yang dikenal dengan konsep pembelajaran elektronik atau elearning. MOODLE dapat digunakan secara bebas sebagai produk sumber terbuka (open source) di bawah lisensi GNU. MOODLE dapat diinstal di komputer dan sistem operasi apapun yang bisa menjalankan PHP dan mendukung database SQL.

\footnotetext{
${ }^{5}$ Ryan K. Ellis, A Field Guide to Learning Management System (Amerika: Society For Training and Development (ASTD, 2009), 1.

${ }^{6}$ Ibid., 5.
} 
Platform berikutnya ialah Claroline. ${ }^{7}$ Platform ini bersifat open source berbasis PHP dan MySQL yang pada awalnya dikembangkan oleh UCL(Universitas Katolik Louvain) di Belgia pada tahun 2001. Proyek LMS yang dibiayain oleh Yayasan Louvain ini dikembangkan mengikuti pengalaman pedagogi dan kebutuhan pengajar. Sejak tahun 2004 sampai dengan 2007, CERDECAM turut memberikan sumbangsih signifikan terhadap pengembangan Claroline. Dibandingkan LMS populer lain seperti Moodle maupun Dokeos, Claroline memiliki tampilan yang sederhana dan ukuran file instalasinya pun kecil. Penggunaannya di Indonesia sudah cukup banyak di sekolah tinggi dan universitas.

Berikutnya adalah Dokeos. Dokeos adalah elearning tools untuk aplikasi berbasis web. Ia merupakan free software yang dirilis oleh GNU GPL dan pengembangannya didukung oleh dunia internasional. Sistem operasinya bersertifikasi yang bisa digunakan sebagai konten dari sistem managemen untuk pendidikan. kontennya meliputi distribusi bahan pelajaran, kalender, progres pembelajaran, percakapan melalui text/audio maupun vidio, administrasi test, dan menyimpan catatan. Pada tahun 2004 dokeos sudah ditranslate ke dalam 31 bahasa dan digunakan oleh lebih dari ratusan organisasi. Tujuan utama dari dokeos adalah menjadi sistem yang userfriendly dan flexibel serta mudah dipakai. Selain itu juga menjadi tool yang bagus untuk pembelajaran sehingga user puas terhadap aplikasi ini.

Platform berikutnya adalah Docebo. Docebo adalah paket software untuk e-learning dan LCMS (Learning Content Management System), dibuat dan dikembangkan oleh Docebo Srl. ${ }^{8}$ Program ini dirilis dalam bentuk lisensi GPL yang artinya tidak memiliki lisensi berbayar. Program ini menggunakan pendekatan multi-model diktat, yang merupakan salah satu platform open source yang paling banyak digunakan dan disukai di level internasional. Kemampuan untuk melakukan personalisasi model diktat sesuai kebutuhan klien membuat Docebo sangat menakjubkan dan fleksibel. Dengan platform sederhana yang dapat dikonfigurasi untuk berbagai kebutuhan yang menggunakan berbagai model diktat, untuk perusahaan besar di sektor keuangan dan asuransi, kesehatan, pemerintahan, universitas dan sekolah.

\section{Blended Learning}

Secara etimologi istilah Blended Learning terdiri dari dua kata yaitu Blended yang berarti campuran dan Learning yang berarti pembelajaran. Dengan demikian sepintas lalu blended learning mengandung makna pola pembelajaran yang mengandung unsur pencampuran atau penggabungan antara satu pola dengan pola yang lainnya dalam pembelajaran. Mosa dalam Kumar mengulas bahwa

\footnotetext{
${ }^{7}$ Ryan K. Ellis, 5.

${ }^{8}$ Ibid.
} 
yang dicampurkan dalam blended learning yaitu dua unsur utama, yakni pembelajarnan di kelas (classroom lesson) dengan online learning. ${ }^{9}$

Blended learning yaitu metode pembelajaran yang memadukan pertemuan tatap muka dengan materi online secara harmonis. Perpaduan antara pembelajaran konvensional di mana pendidik dan peserta didik bertemu langsung dengan pembelajaran secara online yang dapat diakses kapan saja dan di mana saja. Adapun bentuk lain dari blended learning adalah pertemuan virtual antara pendidik dengan peserta didik. Dimana antara pendidik dan peserta didik mungkin saja berada di dua tempat yang berbeda, namun bisa saling memberi feedback, bertanya, atau menjawab. Semuanya dilakukan secara real time.

Regulasi untuk e-learning saat ini juga sedang digodok oleh pemerintah, seperti yang diungkapkan oleh Mentri Riset, Teknologi, dan Pendidikan Tinggi Muhammad Nasir, menjelaskan bahwa regulasi penyelenggaraan e-learning atau kuliah secara daring dalam waktu dekat akan diterbitkan pemerintah. Untuk beralih dari model pembelajaran tatap muka atau bertemu secara langsung, lalu berubah menjadi daring (online) itu sangat membutuhkan effort dan biaya yang tidak sedikit. Namun ini bisa dimulai dengan model Blended Learning. Apa itu blanded learning? Model Blended Learning adalah pada dasarnya merupakan gabungan keunggulan pembelajaran yang dilakukan secara tatap-muka dan secara virtual.

Menurut Semler dalam Soekartiwi, blended learning adalah sebuah kemudahan pembelajaran yang menggabungkan berbagai cara penyampaian, model pengajaran, dan gaya pembelajaran, memperkenalkan berbagai pilihan media dialog antara fasilitator dengan orang yang mendapat pengajaran. ${ }^{10}$ Blended learning juga sebagai sebuah kombinasi pengajaran langsung (faceto-face) dan pengajaran online, tapi lebih daripada itu sebagai elemen dari interaksi sosial. Blended learning merupakan pembelajaran yang didukung oleh kombinasi efektif dari cara penyampaian, cara mengajar dan gaya pembelajaran yang berbeda serta ditemukan pada komunikasi terbuka diantara seluruh bagian yang terlibat dengan pelatihan". Sedangkan untuk keuntungan dari penggunaan blended learning sebagai sebuah kombinasi pengajaran langsung (face-to-face) dan pengajaran online, tapi lebih daripada itu sebagai elemen dari interaksi sosial yaitu: pertama, adanya interaksi antara pengajar dan mahasiswa. Kedua, pengajaran pun bisa secara online ataupun tatap muka langsung. Ketiga, Blended Learning = combining instructional modalities (or delivery media). Keempat, Blended Learning $=$ combining instructional methods.

${ }^{9}$ Jaya Kumar, “Aplikasi ‘E-Learning’ Dalam Pengajaran Dan Pembelajaran Di SekolahSekolah Malaysia,” 2013.

${ }^{10}$ Soekartawi, "Blended E-Learning: Alternatif Model Pembelajaran Jarak Jauh Di Indonesia," Seminar Nasional Aplikasi Teknologi Informasi 2006 (SNATI 2006) 2006, no. Snati (2006): 8 . 
Manfaat dari penggunaan e-learning dan juga blended learning dalam dunia pendidikan saat ini adalah e-learning memberikan fleksibilitas dalam memilih waktu dan tempat untuk mengakses pelajaran. Peserta didik tidak perlu mengadakan perjalanan menuju tempat pelajaran disampaikan, elearning bisa dilakukan dari mana saja baik yang memiliki akses ke Internet ataupun tidak. E-learning memberikan kesempatan bagi siswa/mahasiswa secara mandiri memegang kendali atas keberhasilan belajar. Pembelajar bebas menentukan kapan akan mulai, kapan akan menyelesaikan, dan bagian mana dalam satu modul yang ingin dipelajarinya terlebih dulu. Seandainya, setelah diulang masih ada hal yang belum ia pahami, pembelajar bisa menghubungi instruktur, nara sumber melalui email, chat atau ikut dialog interaktif pada waktu-waktu tertentu. Bisa juga membaca hasil diskusi di message board yang tersedia di LMS. Blended learning memberikan kesempatan yang terbaik untuk belajar dari kelas transisi ke elearning. Blended learning melibatkan kelas (atau tatap muka) dan belajar online. Metode ini sangat efektif untuk menambah efisiensi untuk kelas instruksi dan memungkinkan peningkatan diskusi atau meninjau informasi di luar ruang kelas.

\section{Kualitas Pembelajaran}

Kualitas dapat dimaknai dengan istilah mutu atau keefektifan. Secara definitif, efektivitas dapat dinyatakan sebagai tingkat keberhasilan dalam mencapai tujuan atau sasarannya. ${ }^{11}$ Efektivitas merupakan suatu konsep yang lebih luas mencakup berbagai faktor di dalam maupun di luar diri seseorang. Efektivitas tidak hanya dapat dilihat dari sisi produktivitas, akan tetapi juga dapat pula dilihat dari sisi persepsi atau sikap orangnya. Berdasarkan pendapat tersebut, kualitas pembelajaran ialah tingkat keberhasilan suatu proses pembelajaran dalam mencapai tujuan pengajaran tertentu, sehingga diperoleh proses dan kualitas pembelajaran yang optimal.

Dalam mewujudkan suatu pembelajaran yang berkualitas diperlukan keterkaitan antara indikator-indikatornya. Depdiknas menyebutkan indikator-indikator kualitas pembelajaran meliputi: perilaku pembelajaran guru, perilaku dan dampak belajar siswa, iklim pembelajaran, materi pembelajaran, media pembelajaran, dan sistem pembelajaran. Peneliti akan mengkaji indikatorindikator tersebut ke dalam tiga variabel penelitian yaitu keterampilan guru, aktivitas siswa, dan hasil belajar. ${ }^{12}$ Ketiga variabel tersebut dianggap mampu mewakili enam indikator kualitas pembelajaran.

Selain itu, Mulyasa mengukapkan ada delapan keterampilan mengajar yang sangat berperan dan menentukan kualitas pembelajaran. ${ }^{13}$ Keterampilan tersebut adalah keterampilan bertanya, keterampilan memberi penguatan, keterampilan mengadakan variasi, menjelaskan, membuka dan menutup pembelajaran, membimbing diskusi kelompok kecil, mengelola kelas, serta mengajar kelompok kecil dan perorangan. Hal ini sejalan dengan Anitah, yang menjelaskan bahwa terdapat

\footnotetext{
${ }^{11}$ Hamdani, Strategi Belajar Mengajar (Bandung: Pustaka Setia, 2011), 194.

${ }^{12}$ Depdiknas, 2004.

${ }^{13}$ Mulyasa, Menjadi Guru Profesional Menciptakan Pembelajaran Kreatif Dan Menyenangkan. (Bandung: Ramaja Rosdakarya, 2006), 69.
} 
delapan ketrampilan dasar mengajar yang dianggap berperan penting dalam menentukan keberhasilan pembelajaran. Keterampilan tersebut yaitu: keterampilan bertanya, keterampilan penguatan, keterampilan variasi, keterampilan menjelaskan, keterampilan membuka dan menutup pembelajaran, keterampilan membimbing diskusi kelompok kecil, keterampilan mengelola kelas, keterampilan mengajar kelompok kecil dan perorangan. ${ }^{14}$ Keterampilan-keterampilan ini perlu mendapat perhatian dari guru PAK dalam meningkatkan kualitas dan hasil belajar peserta didik.

\section{Adaptasi Kebiasaan Baru}

Pengaruh pandemi Covid-19 memang benar-benar luar biasa. Covid-19 ditandai dengan munculnya gejala batuk pilek, flu, demam, gangguan pernapasan, namun ada juga yang tidak nampak/muncul gejalanya, dan dalam kondisi parah bisa menyebabkan gagal napas dan berakhir pada kematian. Penularannya melalui droplets atau percikan batuk atau bersin. Virus dapat berpindah secara langsung melalui percikan batuk atau bersin dan napas orang yang terinfeksi yang kemudian terhirup orang sehat. Virus juga dapat menyebar secara tidak langsung melalui benda-benda yang tercemar virus akibat percikan atau sentuhan tangan yang tercemar virus. Virus bisa tertinggal di permukaan benda-benda dan hidup selama beberapa jam hingga beberapa hari, namun cairan disinfektan dapat membunuhnya. Penyakit ini belum ada obat/vaksinnya dan sudah menjadi pandemi yang menyebabkan banyak kematian di dunia maupun di Indonesia. Untuk melawan virus ini, hal utama yang perlu dilakukan adalah melakukan tindakan pencegahan seperti: sering cuci tangan pakai sabun, menerapkan etika batuk atau pakai masker, meningkatkan daya tahan tubuh, menjaga jarak, dan menghindari kerumunan.

Pada masa pandemi masyarakat Indonesia diharuskan hidup dengan tatanan hidup baru, yang dapat 'berdamai' dengan COVID-19. Adapun yang dimaksud dengan New Normal adalah suatu tindakan atau perilaku yang dilakukan oleh masyarakat dan semua institusi yang ada di wilayah tersebut untuk melakukan pola harian atau pola kerja atau pola hidup baru yang berbeda dengan sebelumnya. Bila hal ini tidak dilakukan, akan terjadi risiko penularan. Tujuan dari New Normal adalah agar masyarakat tetap produktif dan aman dari Covid-19 di masa pandemi. New Normal lebih mudah diinternalisasikan oleh masyarakat. New Normal dinarasikan menjadi “Adaptasi Kebiasaan Baru.” Maksud dari Adaptasi Kebiasaan Baru adalah agar masyarakat dapat bekerja, belajar, dan beraktivitas dengan produktif di era Pandemi Covid-19.

\footnotetext{
${ }^{14}$ Anitah S., Media Pembelajaran (Surakarta: Yuma Pustaka, 2009), 72.
} 


\section{Pendidikan Agama Kristen}

Homrighausen dan Enklaar menjelaskan bahwa PAK berpangkal pada persekutuan umat Tuhan. ${ }^{15}$ Dalam Perjanjian Lama pada hakekatnya dasar-dasar terdapat pada sejarah suci purbakala, bahwa PAK itu mulai sejak terpanggilnya Abraham menjadi nenek moyang umat pilihan Tuhan, bahkan bertumpu pada Allah sendiri karena Allah menjadi peserta didik bagi umat-Nya. Warner C. Graedorf dalam Kristanto, PAK adalah proses pengajaran dan pembelajaran yang berdasarkan Alkitab, berpusat pada Kristus, dan bergantung kepada Roh Kudus. ${ }^{16}$ Kemudian membimbing setiap pribadi pada semua tingkat pertumbuhan melalui pengajaran masa kini ke arah pengenalan dan pengalaman rencana dan kehendak Allah melalui Kristus dalam setiap aspek kehidupan, dan melengkapi mereka bagi pelayanan yang efektif, yang berpusat pada Kristus sang Guru Agung dan perintah yang mendewasakan pada murid.

Berdasarkan pembahasan di atas, rumusan masalah dalam penelitian ini adalah bagaimana penerapan Learning Management System dan Blended Learning sebagai alternatif model merdeka belajar di masa adaptasi Kebiasaan Baru (New Normal)? Serta bagaimana implementasi sistem pembelajaran tersebut dalam meningkatkan kualitas pembelajaran agama Kristen di kelas 4 Semester 1 Tahun Pelajaran 2020/2021 Di SDN 8 Selat Hilir? Adapun tujuan penelitian ini adalah untuk mengetahui implementasi dari penerapan Learning Management System dan Blended Learning sebagai alternatif model merdeka belajar di masa adaptasi Kebiasaan Baru (New Normal di kelas 4 Semester 1 Tahun Pelajaran 2020/2021 Di SDN 8 Selat Hilir. Untuk mencapai tujuan penelitian ini, penulis menggunakan pendekatan atau metode Penelitian Tindakan Kelas (PTK).

\section{B. METODOLOGI}

Metode yang digunakan dalam penelitian ini adalah Penelitian Tindakan Kelas (PTK). PTK adalah suatu pencermatan terhadap kegiatan belajar berupa tindakan dari guru yang sengaja dimunculkan dan terjadi dalam sebuah kelas secara bersamaan. ${ }^{17}$ Penelitian ini dilaksanakan dalam dua siklus, dimana satu siklus terdiri atas tiga kali pertemuan. Setiap siklusnya terdiri dari tahap: perencanaan tindakan (plan), pelaksanaan (act), pengamatan (observe), dan refleksi (reflect). Perencanaan disesuaikan dengan metode pembelajaran yang akan digunakan dalam proses pembelajaran selanjutnya. Sedangkan pelaksanaan pembelajaran merupakan langkah nyata terhadap proses pembelajaran di kelas yang melibatkan aktivitas langsung baik guru maupun peserta didik. Observasi ini nantinya menjadi rujukan awal terhadap data konkret pada proses pembelajaran dan hasil belajar peserta didik. Evaluasi merupakan langkah untuk mengukur ketercapaian hasil belajar Mulia, 2013), 12.

${ }^{15}$ E. G. Homrighausen dan I. H. Enklaar, Pendidikan Agama Kristen (Jakarta: BPK Gunung

${ }^{16}$ Paulus Lilik Kristanto, Prinsip dan Praktek PAK Penuntun Bagi Mahasiswa Teologi Dan PAK, Pelayan Gereja, Guru Agama Dan Keluarga Kristen (Yogyakarta: Andi Offset, 2007), 4.

${ }^{17}$ Suwandi, Memahami Penelitian Kualitatif (Jakarta: Rineka Cipta, 2010), 10. 
peserta didik. Hasil belajar tersebut perlu dianalisa secara cermat yang nantinya menjadi data penting sebagai refleksi kegiatan belajar mengajar terlebih mengenai penggunaan metode pembelajaran.

Subjek penelitian ini adalah guru PAK dan peserta didik kelas 4 SDN 8 Selat Hilir Kecamatan Selat Kabupaten Kapuas Provinsi Kalimantan Tengah. Teknik pengumpulan data yang digunakan adalah observasi dan dokumentasi (tes). Sementara teknik analisa data yang digunakan dalam penelitian ini adalah teknik analisa data deskriptif. Menurut Arikunto, teknik ini digunakan untuk mendeskripsikan data yang diperoleh. ${ }^{18}$ Fungsi teknik analisa data yang digunakan untuk memperoleh gambaran tentang hasil belajar. Hasil analisa data menjadi kesimpulan dalam penelitian ini.

\section{PEMBAHASAN}

Pengumpulan data yang dilakukan dalam penelitian ini adalah data hasil observasi dan hasil pekerjaan peserta didik (tes) dalam pembelajaran agama Kristen. Teknik tes berupa soal berjumlah 16 soal pilihan ganda. Teknik tes digunakan untuk peningkatan kualitas pembelajaran tentang materi "Memahami Kehadiran Allah Dalam Berbagai Peristiwa Kehidupan" dengan menggunakan Learning Management System dan Blended Learning. Berdasarkan pedoman penilaian di atas, dipahami bahwa hasil belajar peserta didik dalam materi tersebut, mencapai hasil belajar yang di harapkan dengan $\mathrm{KKM} \geq 70$. Kriteria untuk mengukur tingkat pencapaian keberhasilan pembelajaran dinyatakan telah mencapai tujuan pembelajaran, jika total nilai rata-rata kelas telah mencapai $\geq 70 \%$. Proses perbaikan pembelajaran dinyatakan telah mencapai tujuan pembelajaran, jika jumlah siswa yang paham atau menguasai materi Memahami Kehadiran Allah Dalam Berbagai Peristiwa Kehidupan $\geq 70 \%$.

Setelah melaksanankan proses pada siklus I dan siklus II, hasil kualitas pembelajaran guru PAK dan peserta didik selama proses pembelajaran berlangsung yang dinilai melalui lembar Kondisi Awal (Pra Siklus). Berikut hasil belajar peserta didik dari pra siklus sampai ke siklus ke II:

\section{a. Hasil Penelitian Siklus I}

Hasil analisis siklus I dapat diuraikan sebagai berikut: pertama, analisis. Dari hasil data yang didapat oleh observeri (PraSIKLUS), maka proses belajar mengajar yang telah dilakukan dianalisis: proses pembelajaran kurang menarik, kurang lancar dan kurang menyanangkan bagi siswa sehingga siswa kurang bersemangat dalam menerima pelajaran, serta guru tidak menggunakan pendekatan, strategi dan metode pembelajaran yang variatif kususnya di masa pademi covid 19 yang telah melanda Indonesia. Kedua, sintesis. Pada siklus ini dari proses pembelajaran yang telah dilakukan mulai dari perencanaan sampai pada akhir kegiatan, ternyata belum dapat meningkatkan pemahaman siswa sesuai dengan apa yang diharapkan oleh guru. Hal ini disebabkan karena masih adanya kelemahan yang

\footnotetext{
${ }^{18}$ Suharsimi Arikunto, Prosedur Penelitian: Suatu Pendekatan Praktik (Jakarta: Rineka Cipta, 2010), 23.
} 
ditemui sehingga masih menjadi rintangan dalam mencapai peningkatan pemahaman siswa sehingga perlu dilakukan pembelajaran pada siklus II selanjutnya.

Ketiga, evaluasi. Berdasarkan hasil data, pada proses pembelajaran pada siklus I ini setelah menerapkan Learning Management System dan Blended Learning alternatif model Merdeka Belajar di masa adaptasi Kebiasaan Baru (New Normal), memperlihatkan bahwa proses pembelajaran materi Pendidikan Agama Kristen Memahami Kehadiran Allah Dalam Berbagai Peristiwa

Kehidupanmemperlihatkan bahwa tingkat Meningkatkan Kualitas Pembelajaran siswa secara klasikal masih di bawah standar, yaitu dari 4 orang siswa, nilai rata-rata kelas 68,75 dengan 2 siswa tuntas atau $50 \%$ yang tuntas dari 4 sedikit lagi mendapai nilai $\mathrm{KKM} \geq 70$ yang diharapkan, maka untuk itu perlu dilakukan kembali Siklus yang kedua.

\section{b. Hasil Penelitian Siklus II}

Hasil observasi proses pembelajaran pada siklus II menunjukkan hal-hal sebagai berikut: pertama, siswa mulai lebih aktif dalam kegiatan belajar, hal ini disebabkan karena guru sudah banyak memberikan bimbingan dan pengayaan tambahan atau penjelasan. Siswa lebih cepat dapat menerapkan Persiapan, Pelaksanaan, dan Hasil pada kegiatan pembelajaran PAK materi "Memahami Kehadiran Allah Dalam Berbagai Peristiwa Kehidupan,” guru telah mencoba menerapkan Learning Management System dan Blended Learning sebagai alternative model Merdeka Belajar di Masa adaptasi Kebiasaan Baru (New Normal) dalam rangka meningkatkan kualitas pembelajaran siswa Kelas 4 Semester 1 Tahun Pelajaran 2020/2021 di SDN 8 Selat Hilir pada pelajaran PAK. Hasil belajar siswa meningkat siknifikan ke angka rata-rata kelas 85,94 dengan 3 siswa tuntas atau $\geq 70 \%$ dari 4 siswa dan telah melebihi $\mathrm{KKM} \geq 70$.

Kedua, hasil refleksi. Setelah dilakukan siklus II, dengan kelas yang dilakukan sesuai dengan perencanaan dan skenario pembelajaran, maka proses pembelajaran berjalan dengan baik serta suasana kelas yang kondusif. Kemudian dari hasil analisis dapat disimpulkan bahwa kelemahan-kelemahan dan kekurangan pada proses pembelajaran siklus I telah dapat diatasi dengan baik. Dengan kata lain perbaikan pembelajaran PAK tentang materi "Memahami Kehadiran Allah Dalam Berbagai Peristiwa Kehidupan” di Kelas 4 Semester 1 Tahun Pelajaran 2020/2021 Di SDN 8 Selat Hilir telah berhasil meningkatkan hasil belajar siswa. Hasil evaluasi proses perbaikan pembelajaran PAK membuktikan bahwa terjadi perubahan peningkatan kualitas belajar siswa yaitu rata-rata kelas 56,25 dengan 3 siswa tidak tuntas atau $75 \%$ yang tuntas dari 4 pada prasiklus, berubah 85,94 dengan 3 siswa tuntas atau $\geq 70 \%$ yang tuntas dari 4 pada siklus II.

\section{KESIMPULAN}

Berdasarkan hasil penelitian dan pembahasan, diperoleh kesimpulan bahwa penerapan Learning Management System dan Blended Learning sebagai alternatif model Merdeka Belajar di 
masa adaptasi Kebiasaan Baru (New Normal) yang digunakan pada pelajaran PAK pada materi "Memahami Kehadiran Allah Dalam Berbagai Peristiwa Kehidupan," dapat meningkatkan kualitas pembelajaran siswa kelas 4 Semester 1 Tahun Pelajaran 2020/2021 di SDN 8 Selat Hilir. Hal ini terbukti pada Prasiklus skor rata-rata nilai belajar siswa 56,25 dengan 1 dari 4 siswa yang tuntas, meningkat pada siklus I yaitu 68,75 dengan 2 siswa yang tuntas. Kemudian pada siklus II meningkat lagi yaitu 85,94 dengan 3 siswa yang tuntas dari 4 siswa di kelas 4 Semester 1 Tahun Pelajaran 2020/2021 Di SDN 8 Selat Hilir. Demikian juga pada persentasi ketuntasan meningkat dari Prasiklus 25\%, meningkat pada siklus I sejumlah 50\%, serta meningkat lagi menjadi 70\% pada siklus II.

Saran yang dapat penulis berikan dari hasil penelitian ini adalah: pertama, penerapan Learning Management System dan Blended Learning alternatif model Merdeka Belajar di masa adaptasi Kebiasaan Baru (New Normal) untuk meningkatkan kualitas pembelajaran kelas 4 Semester 1 Tahun Pelajaran 2020/2021 Di SDN 8 Selat Hilir, pada mata pelajaran PAK materi tentang "Memahami Kehadiran Allah Dalam Berbagai Peristiwa Kehidupan," dapat digunakan dalam proses pembelajaran siswa dimasa pandemi. Kedua, pendidik atau guru PAK dapat secara aktif kreatif membuat kondisi kelas yang menyenangkan dan responsif guna meningkatkan semangat dalam pembelajaran yang akan diikuti oleh para siswa, serta pelunya melakukan kerjasama dalam proses pembelajaran guna mencapai tujuan pembelajaran yang telah dirumuskan sebelumnya. Ketiga, dalam menerapkan Learning Management System dan Blended Learning sebagai alternatif Model Merdeka Belajar di masa adaptasi Kebiasaan Baru (New Normal), memerlukan keuletan yang dalam baik dari siswa maupun pendidik guna menciptakan suasana belajar yang lebih efektif dan efisien. Keempat, membutuhkan banyak waktu dalam proses penerapan Learning Management System dan Blended Learning sebagai alternative model Merdeka Belajar di masa adaptasi Kebiasaan Baru (New Normal), untuk meningkatkan kualitas pembelajaran PAK di Kelas 4 Semester 1 Tahun Pelajaran 2020/2021 Di SDN 8 Selat Hilir. 


\section{DAFTAR PUSTAKA}

Arikunto, Suharsimi. Prosedur Penelitian: Suatu Pendekatan Praktik. Jakarta: Rineka Cipta, 2010. Ellis, Ryan K. A Field Guide to Learning Management System. Amerika: Society For Training and Development (ASTD, 2009.

Gidion, Gidion. "Kecakapan Lulusan Pendidikan Tinggi Teologi Menghadapi Kebutuhan Pelayanan Gereja dan Dunia Pendidikan Kristen." KURIOS (Jurnal Teologi dan Pendidikan Agama Kristen) 6.1 (2020): 73-86.

Hamdani. Strategi Belajar Mengajar. Bandung: Pustaka Setia, 2011.

Homrighausen, E. G. dan I. H. Enklaar. Pendidikan Agama Kristen. Jakarta: BPK Gunung Mulia, 2013.

Hutapea, Rinto Hasiholan. "Model Pembelajaran Kooperatif Tipe Make a Match Dalam Pendidikan Agama Kristen." SOTIRIA: Jurnal Teologi dan Pelayanan Kristiani 3, no. 1 (2020): 1-10.

Kristanto, Paulus Lilik. Prinsip Dan Praktek PAK Penuntun Bagi Mahasiswa Teologi Dan PAK, Pelayan Gereja, Guru Agama Dan Keluarga Kristen. Yogyakarta: Andi Offset, 2007.

Kumar, Jaya. “Aplikasi 'E-Learning' Dalam Pengajaran Dan Pembelajaran Di Sekolah-Sekolah Malaysia," 2013.

Mulyasa. Menjadi Guru Profesional Menciptakan Pembelajaran Kreatif Dan Menyenangkan. Bandung: Ramaja Rosdakarya, 2006.

S., Anitah. Media Pembelajaran. Surakarta: Yuma Pustaka, 2009.

Samarenna, Desti. "WABAH COVID-19 DAN JAMINAN PERLINDUNGAN ALLAH DALAM MAZMUR 23." SHIFTKEY (JURNAL TEOLOGI DAN PENGEMBANGAN PELAYANAN) 10, no. 1 (2020).

Soekartawi. "Blended E-Learning: Alternatif Model Pembelajaran Jarak Jauh Di Indonesia." Seminar Nasional Aplikasi Teknologi Informasi 2006 (SNATI 2006) 2006, no. Snati (2006): 8.

Suwandi. Memahami Penelitian Kualitatif. Jakarta: Rineka Cipta, 2010.

Yulia, Tantri. "PENGGUNAAN MEDIA PEMBELAJARAN OLEH PENDIDIK PAK SEMESTER GENAP TA 2016-2017 DI STT KRISTUS ALFA OMEGA SEMARANG.” SHIFTKEY (JURNAL TEOLOGI DAN PENGEMBANGAN PELAYANAN) 7, no. 2 (2017). 